\title{
. A RED-BLOODED PASSION FOR THE GREEN-FINGERED
}

\author{
DR CHRIS MARBLE IS AN ENVIRONMENTAL HORTICULTURIST \\ BASED AT THE UNIVERSITY OF FLORIDA IN THE US. HIS WORK \\ FOCUSES ON DEVELOPING WAYS OF IMPROVING WEED \\ CONTROL IN VARIOUS SETTINGS. THE FINDINGS COULD \\ BENEFIT FARMERS AND GARDENERS AROUND THE WORLD
}

The dictionary defines a weed as a, "wild plant growing where it is not wanted and in competition with cultivated plants'. People who are considered feeble have been insulted as 'weeds', while to 'weed out' is to remove something from where it is not wanted. The connotations of weeds are almost exclusively negative and with good reason - they are the bane of budding gardener's lives all around the world.

Such is the extent of interest in finding ways to remove weeds that the US even has its own Weed Science Society of America - an organisation dedicated to understanding the impact of weeds on ecosystems. This interest in weeds and how best to control them is something that $\mathrm{Dr}$ Chris Marble can appreciate - he has dedicated most of his professional life to studying weeds, and specialises in invasive weed management. Based at the Mid-Florida Research \& Education Center within the University of Florida in the US, Chris is currently working on a project that seeks to improve weed control in ornamental nurseries, greenhouses and landscapes.

WHAT ARE THE MAIN PROBLEMS WITH CURRENT WEED CONTROL PRACTICES? Hand weeding is a common means of controlling weeds and, as the name suggests, it involves uprooting weeds by hand or with tools. While this method is relatively successful, it is extremely time-consuming and expensive. Then there is the use of herbicides to kill the weeds - again, a successful method, but one that can cost thousands of dollars per year. The knock-on effect of these methods is a significant reduction in profits and the overall sustainability of the industry. This is something that Chris and his team want to address in their research.

\section{WHAT CHALLENGES DID THE}

PROJECT POSE FOR CHRIS AS A HORTICULTURIST?

The biggest challenge for Chris is trying to come up with ways to improve weed control that can be implemented across many different nurseries. "A field crop grower might grow one crop, like corn or soybeans or peanuts. In contrast, a nursery (ornamental plant) grower might have 500 different plants that they have to grow," explains Chris. "Many of these will require different fertilisation, irrigation, pruning, etc. They will also have to use different pesticides for many of those plants. Coming up with something that works for everyone is very difficult."

WHAT STRATEGIES DID CHRIS DEVELOP AND IMPLEMENT IN THE PROJECT?

The team has been researching how things like fertilisation practices, potting soils and irrigation scheduling can be changed in order to reduce weed growth and encourage highly marketable plants. Chris's concerns revolve around implementing strategies that are environmentally friendly and consider the bigger picture. Part of this approach explains why the team wants to try and alter production practices to increase the 

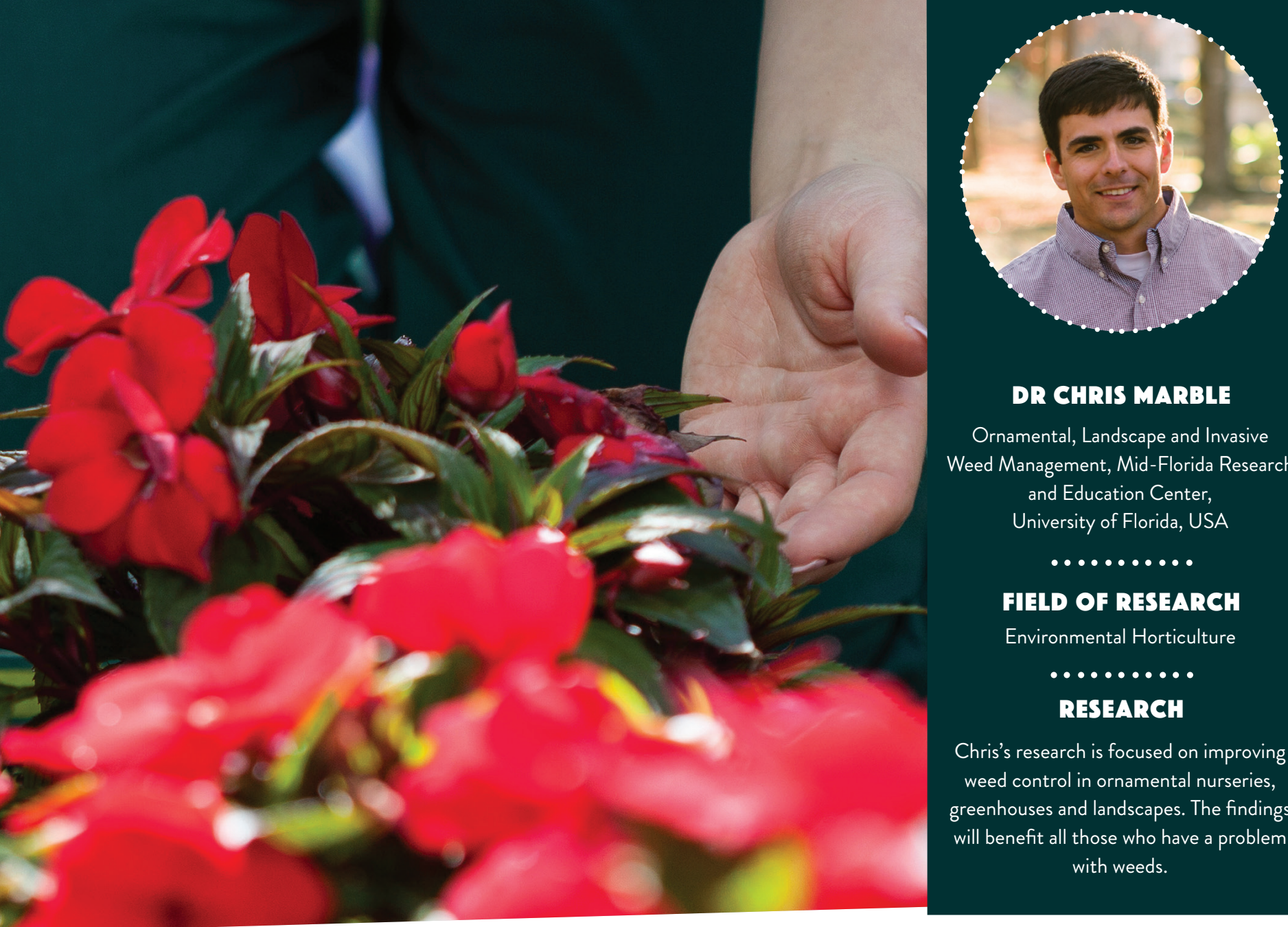

DR CHRIS MARBLE

Ornamental, Landscape and Invasive Weed Management, Mid-Florida Research and Education Center,

University of Florida, USA

\section{FIELD OF RFSEARCH}

Environmental Horticulture

\section{DESTARGH}

Chris's research is focused on improving weed control in ornamental nurseries, greenhouses and landscapes. The findings will benefit all those who have a problem with weeds.

effectiveness of herbicides and therefore reduce the total amount of herbicide that is needed.

After thinking of new strategies, Chris and his team test them out in the lab under controlled conditions. If they work, they test them in the field, to make sure they work in the 'real world'. "We want these strategies to work for growers across the globe, so it is important to test them out in a variety of different environments," says Chris. "We also do on-farm research experiments with other researchers across the US."

WHAT HAVE BEEN THE MOST

SIGNIFICANT FINDINGS?

By altering the placement of fertiliser and the physical properties of the potting soil, the team has managed to reduce weed growth. The reason this is important is that it is a relatively simple strategy and one that can be adopted by growers who are unable to use herbicides.

The next step is to apply the findings to reallife situations. Chris is aware that which of his team's findings will be adopted is heavily dependent on the particular nursery. "Some nurseries are more likely to adopt changes in their preemergence herbicide programmes based on our research," explains Chris. "There will be others who might find using mulch or altering fertiliser placement most beneficial."
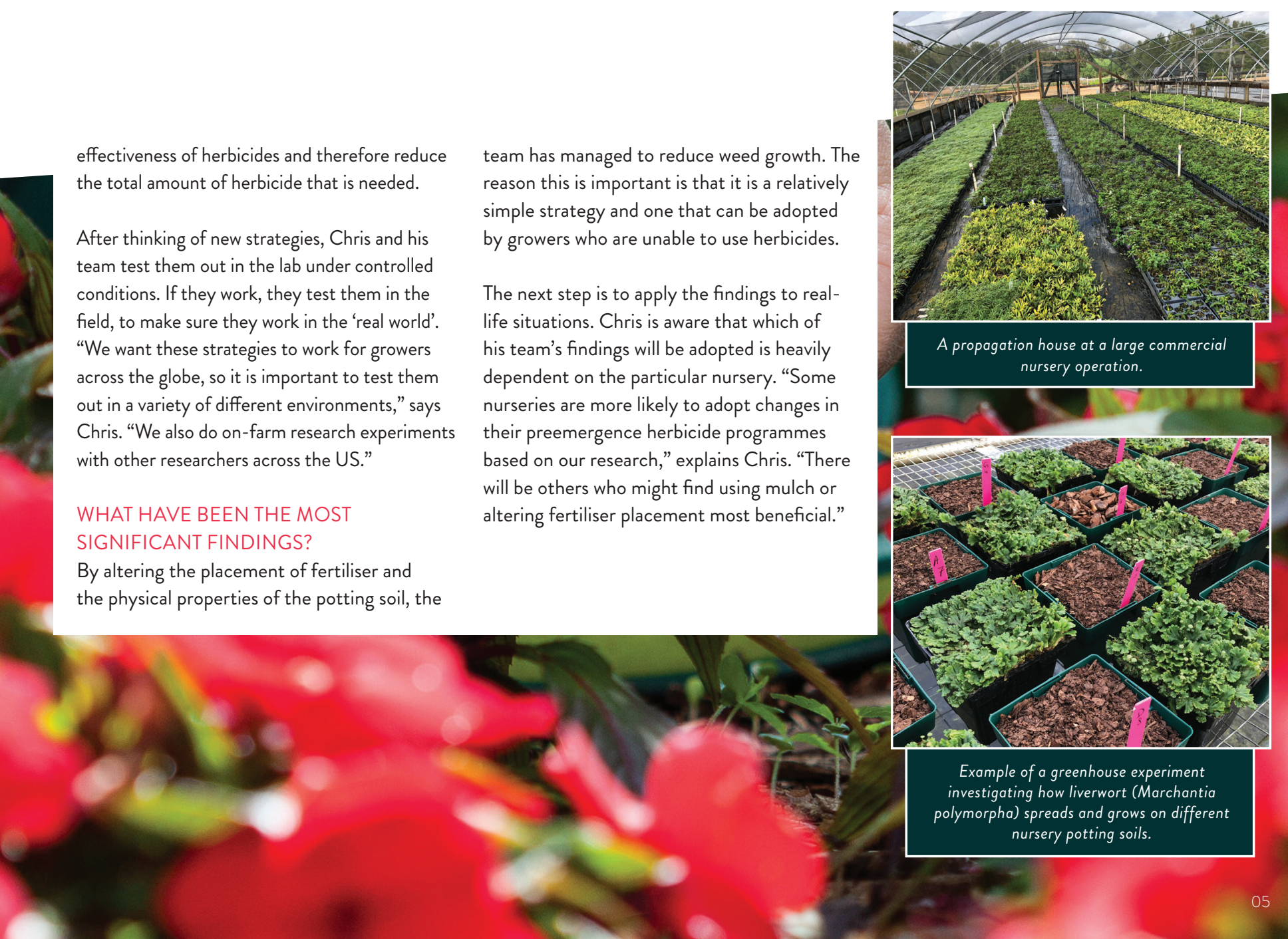

(3)
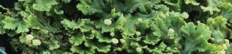

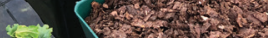

Example of a greenhouse experiment investigating how liverwort (Marchantia polymorpha) spreads and grows on different nursery potting soils. 


\section{ABOUT ENVIRONMENTAL HORTICULTURE}

Humans have been gardening for thousands of years. According to Britannica, western gardening had its origins in Egypt around 4,000 years ago ${ }^{1}$ (although the practice of cultivating plants has certainly existed for much longer, with some reports suggesting 10,000 years). ${ }^{2}$ However, it wasn't until 1806, when the Horticultural Society of London was established in England, that horticulture was viewed as a science.

In the centuries since then, a raft of degrees, masters and $\mathrm{PhDs}$, centres, programmes, universities and other institutions have been created. Chris is a faculty member at the University of Florida's Mid-Florida Research and Education Center which has a stated mission of profitable yet environmentally responsible production and use of high-value horticulture plants and plant products to satisfy demand driven by consumer tastes, preferences, and wellness.

Imagine being fascinated by plants and the science of them and working with them every day of your professional life! It is a dream that Chris has made reality.

\section{WHAT DOES CHRIS FIND MOST} REWARDING ABOUT HIS RESEARCH? Chris says that the most challenging and rewarding aspect of his work is the fact that he does not work on one or even a few different types of plant. "We work with thousands of different types of plants succulents, flowers, herbs, medicinal plants, shrubs, trees. You name it and someone in environmental horticulture is working with that species," says Chris. "This diversity keeps things exciting and allows us the chance to work with and help many different kinds of people and industries."

However, while Chris loves that part of his research, he is keen to emphasise just how much he enjoys working with students.

"Being able to help students develop new skills, learn about horticulture, science and research, and then watch them advance and be successful in their own right is why I do what I do," says Chris.

\section{WHAT WOULD CHRIS'S DREAM} WORK PROJECT BE?

Chris is unequivocal in his belief that he already gets to work on his dream project every day. One of his main passions is helping growers and the landscape industry solve real-world weed management challenges. Every day provides something different, whether it is a new weed, a new invasive plant or a different management scenario, and finding ways to solve these problems is what he wants to continue doing long into the future.

\section{WHAT ARE THE MOST PRESSING} ISSUES FACING TODAY'S HORTICULTURISTS?

Somewhat surprisingly, student enrolment in horticulture programmes is decreasing at some universities. Chris thinks there are many reasons for this but believes that those within academia and industry need to do a better job at demonstrating just how many different career opportunities there are within the sector. "Do you like art? Then get involved with landscape and floral design! Enjoy business, sales, or marketing? Many large nurseries and horticultural product companies have large sales and marketing teams!" says Chris. "There are countless opportunities for you in horticulture and plant sciences."

Chris loves what he does; many of you would find a career in horticulture rewarding too. Which route will you explore?

${ }^{1}$ www.britannica.com/science/gardening/Choice-ofplants

${ }^{2}$ https://hort.purdue.edu/newcrop/originhorttech.pdf

\section{HOW TO BECOME AN} EYMIRONMENIAL HORTICULTURIST

- The American Horticultural Society is one of the best resources out there for aspiring horticulturists. https://ahsgardening.org/

- This article in Guardian Careers discusses Sarah Chesters' experience of changing to a career in horticulture. It provides some handy hints and tips. https://www.theguardian.com/careers/ couture-to-compost-blossoming-careerhorticulture

- The average salary for a horticulturist in the US is $\$ 67,505$ although this is highly dependent on the specific area you work in. Wages typically start from $\$ 35,208$ and go up to $\$ 129,429$.

\section{PATHWAY FROM SCHOOL TO ENYIRONMENTAL HORIICULTURE}

2 or $3 \mathrm{~A}$ levels, or equivalent.

Environmental horticulture is such a broad subject that Chris is keen to emphasise that the pathway you should take is highly dependent on the specific area you want to work in. "Some biology, physiology, environmental sciences or ecology subjects would all be helpful, but on a more specific level, soil sciences, plant sciences and then subjects like entomology or pathology would help if you wanted to work closely with plants," says Chris. "Business courses, like accounting, are great if you want to own your own business some day."

https://www.hortweek.com/career-horticulture/horticulturecareers/article/1523703 


\section{. HOW DID DR CHRIS MARBLE BECOME AN ENVIRONMENTAL HORTICULTURIST?}

WHAT WERE YOUR INTERESTS AS

A CHILD? DID YOU ALWAYS KNOW YOU WANTED TO BE A SCIENTIST? I enjoyed the regular stuff like playing sports and playing outside, seeing what I could get into. In high school, I was more interested in subjects like history and literature and my interest in science didn't really start until I went to college.

\section{HOW DO YOU 'SWITCH OFF'}

\section{FROM WORK?}

I switch off by lifting weights, running and doing anything that is 'mindless', like doing chores around my home. I love to work in my garden, growing vegetables, and cooking. I also read three or four books per month, all non-fiction.
WHO OR WHAT HAS INSPIRED YOU IN YOUR CAREER?

My biggest influencers were my advisors in graduate school who taught me how to be a scientist. I have also had the opportunity to work with, and for, some great scientists who taught me a lot. Being at the University of Florida, I am inspired every day by the people I get to work with right down the hall from my office.

\section{WHAT ARE YOUR PROUDEST} ACHIEVEMENTS?

My proudest achievements are all my students' achievements - both while they are working with me and then after they graduate. Nothing I do would be possible

\section{CHRIS'S TOP TIPS}

1 If you want to work in academia, you really need to learn to love to write. Writing is the lifeblood of an academic, but you will be writing about subjects that you are very interested in.

2 Try and work on projects that interest you and you are passionate about. As a researcher, you are going to be putting in a lot of hours, but if you love the subject, it will never feel like work.

3 Whatever you can do to improve your communication skills and abilities will be extremely helpful in the sciences - or in any career you decide to pursue!
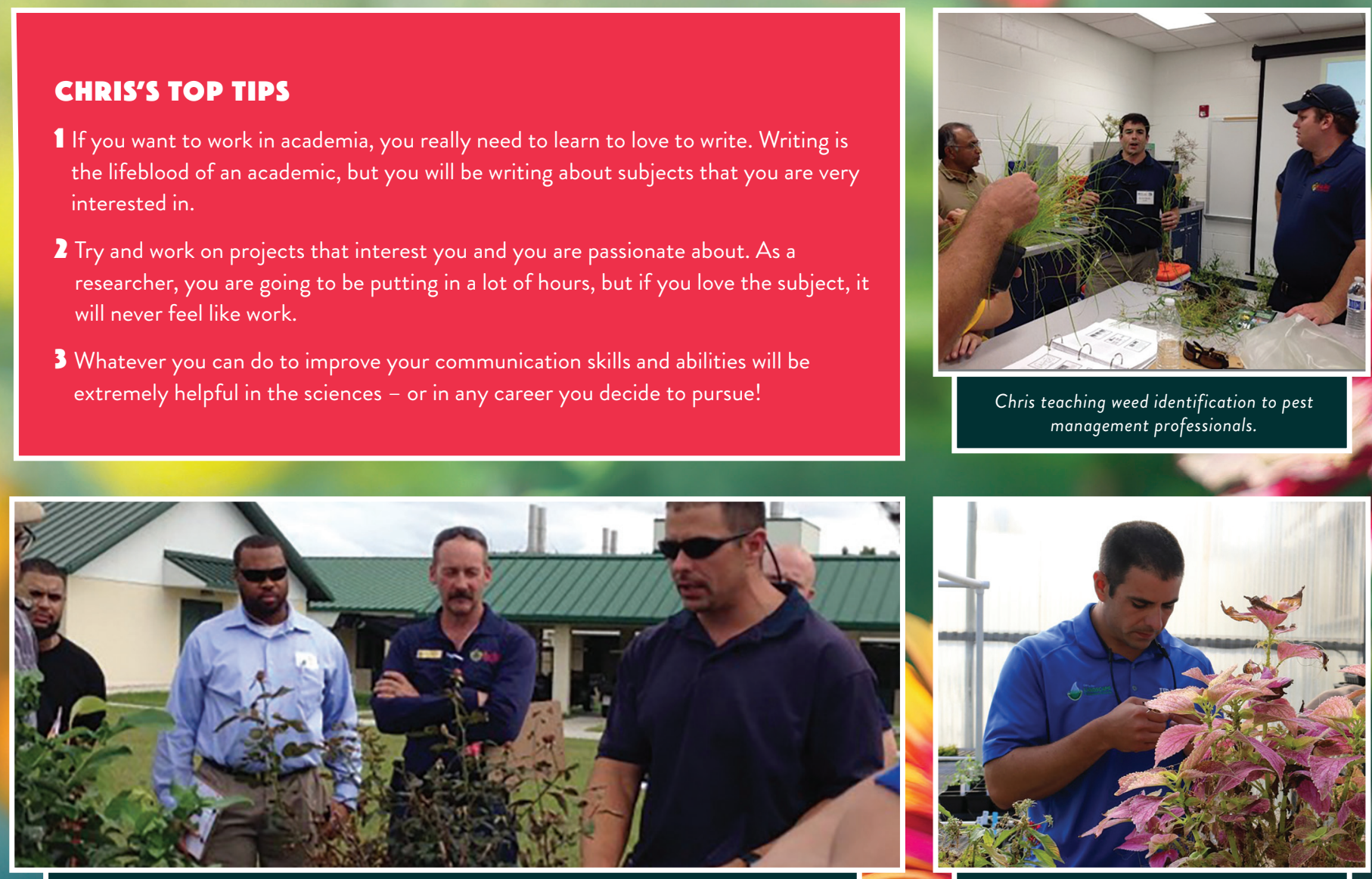

WHAT NON WORK-RELATED GOAL IS AT THE TOP OF YOUR ‘BUCKET LIST'?

Most of my goals are work or career oriented. Some bucket list items would be visiting every US state, running an ultra-marathon and learning Spanish!

without their hard work and the commitment of all the other staff in my programme.
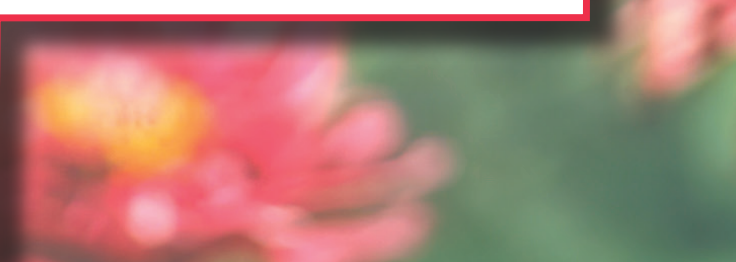